Patronem, ualde Phaedrum amauit, 13.1.5), an exemplum that the learned Memmius may want to follow.

What, then, do these Lucretian echoes add to Cicero's letter and to our understanding of his epistolary communication with Memmius? Cicero can assume that Memmius is familiar with Lucretius' work (as is Atticus, who also was provided a copy of this letter; cf. Att. 5.11.6) and that Lucretius' Epicurean views could be seen as rather fanatical. He clearly thinks, however, that Lucretius' poetry possesses that special blend of genius and ars which would appeal to his learned readers. These intertextual connections are evoked not only to flatter the erudition of his reader (Memmius, Atticus) and to point to a worthy contemporary poetic expression of Epicureanism. In making them, Cicero expects Memmius to be aware of De Rerum Natura as a whole-its motifs, teachings, themes and diction-and to recognize how Lucretius' work speaks to the matters at hand: namely the devotion of Patro, the polish of Atticus, and the remains of Epicurus' home. While Lucretius, in his zeal, may be considered to be a devotee somewhat like Patro, whose type of Epicureanism might be difficult for Memmius to swallow, Cicero evokes his language to indicate how these honeyed words might make their position more palatable (Lucr. 1.931-50, 4.8-25). Cicero speaks to Memmius in the words of one of his formative Epicurean predecessors, Lucretius, to hint at the proper perspective he should have on this frustrating situation. These intertexts suggest that Memmius should acquiesce to the demands of the Athenian Epicureans, for the sake of his own ataraxia and in deference to Lucretius' view of Epicurus, even if their 'centralized authoritarian strictures' are at odds with his own personal expression of Epicureanism. ${ }^{13}$

Oberlin College

CHRISTOPHER V. TRINACTY ctrinact@oberlin.edu doi:10.1017/S0009838820000221

\title{
ARS ADEO LATET ARTE SVA: WHAT IS ART'S ART?*
}

Textual difficulties as well as problems of content are sometimes prone to being overlooked in famous passages, because their very familiarity tends to stifle reflection on their actual meaning. orandum est, ut sit mens sana in corpore sano (Juv. 10.356) escaped detection as an interpolation until 1970. In di, coeptis (nam uos mutastis et illa) | aspirate meis (Ov. Met. 1.2-3), the reading illas has held its place against the correct illa until $1976 .{ }^{1}$

\footnotetext{
${ }^{13}$ Morgan and Taylor (n. 1) remark on the ability of a Roman intellectual to sympathize with Epicureanism while simultaneously refusing to take seriously the centralized authoritarian strictures of its Athenian school' (at 540).

* I am very grateful to Martin Bauer, Wolfgang Kofler and Bernhard Schirg for comments on an earlier version of this note.

${ }^{1}$ M.D. Reeve, 'Seven notes', CR 20 (1970), 134-6, at 135-6; E.J. Kenney, 'Ovidius prooemians', PCPhS 22 (1976), 46-53.
} 
In the present contribution I would like to show that the words cited in the title are a similar case. The context is as follows (Ov. Met. 10.247-53):
interea niueum mira feliciter arte
sculpsit ebur formamque dedit, qua femina nasci
nulla potest, operisque sui concepit amorem.
uirginis est uerae facies, quam uiuere credas
et, si non obstet reuerentia, uelle moueri;
ars adeo latet arte sua. miratur et haurit
pectore Pygmalion simulati corporis ignes. ${ }^{2}$

The fame which the phrase enjoys is apparently fairly recent and due to the present fascination with the poetological aspects of Augustan poetry. In this context, it has been understood as a brillant self-description of Ovid as a poet at least since the late $1950 \mathrm{~s}^{3}$ Whether this understanding is correct, I shall not discuss. My question is much more elementary: what is ars adeo latet arte sua supposed to mean on the verbal level? More precisely, what does sua mean? How can art be concealed by its own art? What is the art of art presupposed by this expression?

The manuscripts unanimously give the reading as cited. Grammars fail to point out any special use of suus that would elucidate the passage. The commentaries are silent. The translations discount sua altogether. To give just a few examples from the major European languages:

'Art hid with art.' (S. Garth, J. Dryden, et al., 1717)

'So war Kunst umhüllet mit Kunst!' (J.H. Voß, 1789)

'so his art concealed his art.' (B. Moore, 1922)

'tant l'art se dissimule à force d'art.' (G. Lafaye, 1955)

'So lässt Kunst nicht sehen die Kunst.' (R. Suchier and E.G. Schmidt, 1986)

'L'arte era tanto grande da non apparire addirittura.' (G. Faranda Villa, 1994)

'art concealed artfulness.' (C. Martin, 2004)

'è un' arte cosi grande che non si vede.' (G. Chiarini, 2013)

No one seems to know what sua is supposed to mean here.

Is Ovid making use of the rhetorical figure of distinctio, the pointed repetition of the same word within a short space with two different meanings? ${ }^{5}$ Should we take ars as 'art', arte as 'work of art': 'To such a degree art lies hidden in its work of art [that is, in the work of art created by it]'? At least one translator understands the sentence with this sense: 'So vollkommen verbirgt sich im Kunstwerk die Kunst!' (M. von

\footnotetext{
2 The text follows R.J. Tarrant, P. Ovidi Nasonis Metamorphoses (Oxford, 2004).

3 The instances cited by Bömer on Met. 10.252-3 (at 99-100) reach back to 1958. More recently, cf. titles such as L. Spahlinger, Ars latet arte sua: Untersuchungen zur Poetologie in den Metamorphosen Ovids (Berlin, 1996); L. Landolfi and P. Monella (edd.), Ars adeo latet arte sua: riflessioni sull'intertestualità ovidiana (Palermo, 2003); C. Kruse, 'Ars latet arte sua: zur Kunst des Kunstverbergens im Barock', in U. Pfisterer and A. Zimmermann (edd.), Animationen, Transgressionen: Das Kunstwerk als Lebewesen (Berlin, 2005), 95-113.

4 I do not believe that Moore's first 'his' indicates that he takes sua as meaning 'Pygmalion's', but this would in any case be unacceptable. The boldest use Ovid makes of suus occurs at Fast. 6.601 (ipse [sc. Servius Tullius] sub Esquiliis, ubi erat sua regia, caesus) and Met. 15.818-19 (ut [sc. Caesar] deus accedat caelo templisque colatur, | tu facies natusque suus). In both cases, suus refers to the subject of a directly preceding (subordinate or main) clause of the same sentence. Here, by contrast, the last time that Pygmalion occurred as a grammatical subject was two sentences earlier, in lines 247-9.

${ }^{5}$ H. Lausberg, Handbuch der literarischen Rhetorik (Munich, 1973²), 333-5 (§§660-2).
} 
Albrecht, 1981). At first glance, this solution looks attractive. Ovid is no stranger to distinctio - one may think of his play with coire in the story of Narcissus and Echo (Met. 3.385-7) - and if the passage could be understood in such a way it would make perfect sense. However, there are unsurmountable obstacles. To take sua as 'created by it' is hard (even von Albrecht does not seem confident that the pronoun can be understood thus, as he still does not translate it). The necessary change of meaning from ars to arte is difficult to guess for the reader, especially so given its position a few lines after the very same distinction has been expressed by ars and opus (Met. 10.247, 10.249). Finally, there is no plausible example for ars in the sense of 'work of art' in Ovid, and none for the singular of the word in this sense before Late Antiquity. ${ }^{6}$

So emendation is called for. In the Metamorphoses, forms of suus occur as corruptions of nearly a dozen different words, most of which are not very close palaeographically. ${ }^{7}$ In the present case, the frequency of arte sua and related phrases in $\mathrm{Ovid}^{8}$ as well as the occurrence of arte and sui in lines 247 and 249 respectively may have further contributed to provoking scribal error. However, an emendation that is unobjectionable and clearly superior to all others is hard to find. The true solution presumably still remains to be found, but it seems at least worth listing the range of options available. sua could be replaced by another word such as noua ('to such a degree art is concealed by art never seen before') or ipsa ('to such a degree art is concealed by art itself'). Unfortunately, the exact kind of novelty expressed by arte noua would remain unclear, ${ }^{9}$ and the paradox ars latet arte would be somewhat weakened by the addition of an adjective. ipsa would provide good sense, as it would underline this very paradox, and the respective corruption would be paralleled in Met. 9.317 (see n. 7 above); but the rare cases of elision after the third arsis in Ovid are apparently restricted to -que, ${ }^{10}$ and neither arte nor any other form of ars is ever elided despite the word's frequency. Alternatively, one may think of ... latet artificem ('the artificiality slips even the artist's attention'), but the necessary meaning of adeo has no exact parallel among the comparatively few instances of the word in Ovid. ${ }^{11}$ Finally,

${ }^{6}$ TLL 2.673.9-26 (ars significat ipsa artis opera) cites Pont. 2.9.44 (about Phalaris roasting Perillus in the bronze bull created by the latter), quiue repertorem torruit arte sua. But Ars am. 1.655-6 (exactly the same context), neque enim lex aequior ulla est $\mid$ quam necis artifices arte perire sua, shows that arte in both cases refers to a new technique of execution, not to the bull. (Cf. the category 'an invention, device, or contrivance' in $O L D$ s.v. ars 8b.) Note that Prop. 3.9 .12 parua ... arte is wrongly included in $T L L$, since it means 'art manifesting itself in fine detail', cf. S.J. Heyworth and J.H.W. Morwood, A Commentary on Propertius Book 3 (Oxford, 2010), ad loc. (at 86) with reference to Plin. $H N$ 35.67. The first unequivocal instances of ars in the singular as 'work of art' appear to be Ennod. Carm. 2.18.4 and 2.98.2.

7 According to Tarrant's apparatus criticus, these are uertit (Met. 2.21), Caystros (5.386), suis and suem ('swine', 7.435 and 10.710), Sinis (7.440), ipsis (9.317), diu (9.415), uirum (9.723), in (12.268), et eodem (15.570) and manu (15.803).

${ }^{8}$ arte sua: Met. 2.686; Pont. 2.9.44. arte ... sua: Ars am. 1.656. sua ... arte: Trist. 2.450. arte suos: Fast. 2.690. arte suum: Met. 7.305. arte mea: Am. 1.10.60; Ars am. 2.12 (bis); Ars am. 2.162; Rem. am. 385-6 (bis); Rem. am. 702; Her. 5.150; Her. 16.366; Met. 7.176.

9 The only other instance of arte noua in Ovid (Met. 1.709) refers to something more concrete, namely to the newly invented pan pipes. The whole phrase ars latet arte noua appears in line 336 of an elegy by Karl Joseph Michaeler published in Poetarum elegiacorum stilo et sapore Ovidiano scribentium ... Collectionis pars altera (Vienna, 1789), 152. Whether this is a misquotation, a conscious variation or, so to speak, a poetic emendation of the Ovidian paradosis, I cannot tell.

${ }_{10}^{10}$ E.g. Met. 2.383, 10.7, 11.214.

${ }^{11}$ Closest comes Trist. 3.1.77-8 di, precor, atque adeo-neque enim mihi turba roganda est-। Caesar, ades ... Cf. OLD s.v. adeo 6b ('yes, and what is more, or rather') and TLL 1.612.41614.42 ('ad augenda enuntiata'), both of which cite this passage. 
one could also try to punctuate after arte and to continue with an object—but which?governed by miratur. ${ }^{12}$

Universität Innsbruck

MARTIN KORENJAK

martin.korenjak@uibk.ac.at

doi:10.1017/S0009838820000233

\section{AN UNNOTICED REFERENCE TO THE CRITO IN PLOTINUS?}

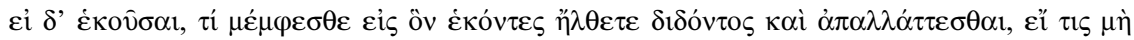

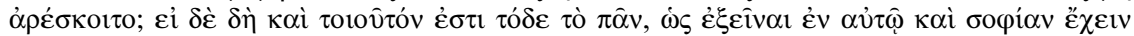

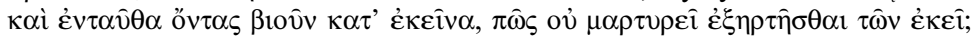

And if they descend willingly, why do you blame the cosmos that you willingly entered and that allows anyone who is not satisfied to escape from it? But if this universe is actually such that we can be in it and have wisdom and while being here live according to those intelligible principles, why wouldn't this bear witness to its dependence on those intelligible principles? ${ }^{1}$

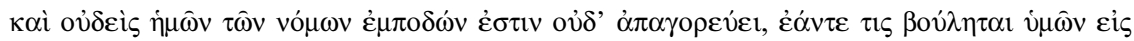

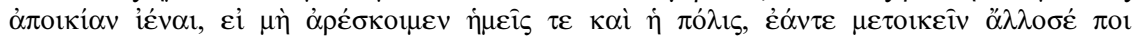

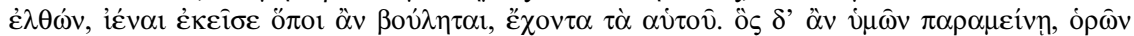

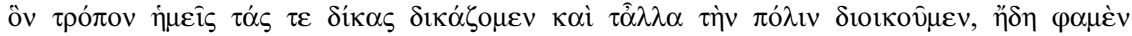

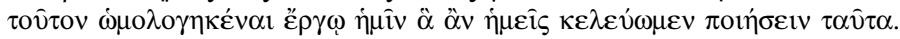

Not one of our laws raises any obstacle or forbids him, if he is not satisfied with us or the city, if one of you wants to go and live in a colony or wants to go anywhere else, and keep his property. We say, however, that whoever of you remains, when he sees how we conduct our trials and manage the city in other ways, has in fact come to an agreement with us to obey our instructions. $^{2}$

At first glance, these two extracts have little in common: this explains why (as far as I know) none of the editors or translators of Plotinus' Enneads ${ }^{3}$ mentions the Crito as a possible influence for this section of the treatise Against the Gnostics. There is, however,

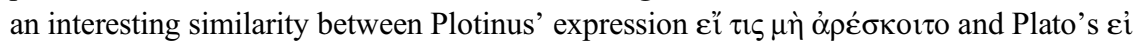
$\mu \grave{\eta} \dot{\alpha} \rho \varepsilon \dot{\varepsilon} \sigma \mu_{\mu \varepsilon v}$ (the first-person plural stands for the laws of Athens). It may still look like an unremarkable coincidence, until we note that these are the only two occurrences of the combination $\varepsilon \dot{\varepsilon}+\mu \dot{\eta}+\dot{\alpha} \rho \dot{\varepsilon} \sigma \kappa \omega$ in the optative passive for the whole TLG corpus. ${ }^{4}$ Would it be possible that the expression was carrying, for a third-century philosopher

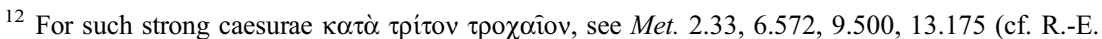
Fuchs, Hexametertypen in Ovids Metamorphosen [Diss., Vienna, 1980], 448-52). The object should not be suam, which would leave the reader wondering whether artem or puellam is the implied noun.

${ }^{1}$ Plotinus, Enn. 2.9 [33].8.42-6, transl. L.P. Gerson et al., Plotinus: The Enneads (Cambridge, 2018).

${ }^{2}$ Pl. Cri. 51d5-e4, transl. G.M.A. Grube, Plato: Five Dialogues (Indianapolis, 1981).

3 Including Gerson et al. (n. 1), 219.

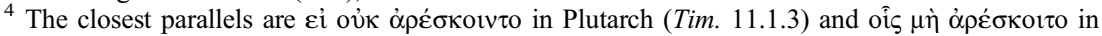
Josephus ( $A J$ 19.179.1). 